\title{
3G MOBILE PHONE ADOPTION AND CONTINUED USE:A PILOT STUDY
}

\author{
Meng Xudong, University of Louisiana at Monroe, mengx@warhawks.ulm.edu \\ Peggy Deal, University of Louisiana at Monroe, bushpa@ warhawks.ulm.edu \\ Liu Li, University of Louisiana at Monroe, liul@warhawks.ulm.edu \\ Christopher Griffin, University of Louisiana at Monroe, cgriffin@ulm.edu \\ William Barnett, University of Louisiana at Monroe, barnett@ulm.edu
}

\begin{abstract}
The third generation (3G) mobile communication standard, paired with advanced cellular phone handsets permit individuals to access an increasing number of web and location based services. Mobile computing platforms represent a very large potential market segment for technology manufacturers and communication service providers. This paper examines the key factors that influence the adoption process and continued use of $3 G$ mobile phones. Based on several well-known theories like Theory of Reasoned Action (TRA), Technology Acceptance Model (TAM), Theory of Planned Behavior (TPB), and Diffusion of Innovation (DOI) the current research attempts to develop a specific and practical model for the process of adopting $3 G$ mobile phones and subsequent continued use by adopters. Data is collected via surveys from potential $3 G$ customers. Descriptive statistics and multinomial regression are used to analyze data, and examine the relationships between constructs.
\end{abstract}

Keywords: 3G, Mobile, Adoption Behavior, Discontinuance

\section{INTRODUCTION}

While Internet and e-commerce have been adopted gradually, the rapid development of wireless technologies makes it possible to work, communicate, or play more easily. Individuals are no longer tied to specific locations to perform various communication activities. For instance, mobile bank and mobile e-mail are both applications which benefit from wireless technology. $3 \mathrm{G}$ is currently on its way to becoming the global standard for enabling interaction with web-based and mobile specific services. This paper examines the current research from the information systems literature on innovation and technology adoption with the goal of developing a conceptual model of $3 \mathrm{G}$ mobile phone technologies. A conceptual model integrating elements from published studies is proposed and

Volume XI, No. 1, 2010 individual influences tested for usefulness in explaining adoption behavior.

\section{Background of 3G Technology}

3G technology, which started in Japan in 2001, has become widespread due to the various applications it brings to mobile phones. It can be regarded as the incremental innovation that arises from previous generations from the $1^{\text {st }}$ generation $(1 \mathrm{G})$ which was started in early 1990s, allowing voice traffic only, through the $2^{\text {nd }}$ generation $(2 \mathrm{G})$ which appeared in 2000s, providing limited data services like short message services (SMS), and lastly to the $2.5 \mathrm{G}$ which showed up between 2000-2002, supporting internet access, data services through Wireless Applications Protocol (WAP).

The primary difference between $3 \mathrm{G}$ and previous wireless communication standards centers around improvements in data transfer rates, and the availability of personalized applications like multimedia messaging (MMS) and GPS. Mobile services that rely the ubiquitous availability of internet connectivity are expected to evolve at a greater rate in conjunction with the availability of high speed data transfer networks [1].

\section{Purpose of the study}

Similar to other information technologies, the adoption of $3 \mathrm{G}$ mobile phones could also be studied by authoritative theories like TRA, TAM, TPB, DOI, Unified Theory of Acceptance and Use of Technology(UTAUT), and so on, which will be reviewed in the following section. This paper will draw upon these theories established theories of technology adoption and innovation diffusion to investigate factors that influence the adoption of $3 \mathrm{G}$ mobile phone technology.

As a new innovation and service, 3G brings uncertainties that may interrupt the purchase. One objective of this paper is to understand customer concerns about adopting or the continued use of $3 \mathrm{G}$ services. The study examines whether the relationships between adoption or continued use, and the influencing factors found in the adoption literature are significant for this technology. Other

Issues in Information Systems 
factors specific to individual adopters and the nature of the mobile computing environment, such as the education level of the customer and perceived affordability of $3 \mathrm{G}$ services are also examined.

\section{LITERATURE REVIEW}

Several theories of technology acceptance have been cited to evaluate the adoption research [2]. Experts in this area have been searching for ways to develop models to reflect the rates of adoption in order to perceive and predict consumer behaviors and their attitudes towards technology innovations. These theories may focus on various different aspects such as marketing and social influences.

\section{Behavioral Theories of Technology Adoption}

The impact perceptions and attitudes held by individual decision makers have been studied extensively in the information systems literature. Several models have been developed that examine technology adoption as a behavioral issue and that have looked to define the factors influencing that behavior. The Theory of Reasoned Action (TRA) describes an individual's attitude towards a behavior as being defined as a person's concept about performing the specified behavior [3]. Subjective norms in the individual's environment, such as social pressure and beliefs primarily account for the individual's adoption. Attitude Towards a Behavior (AB) and Subjective Norms (SN) influence the behavioral intentions (BI) of the decision maker. Relative weights are applied to $\mathrm{AB}$ and $\mathrm{SN}$ to model their relative importance in determining adopter behavior. There are some limitations of the model including a significant risk of confusion between attitudes and norms. The two variables regarded to be independent are not really independent; they relate to and influence one another. Another limitation is the assumption that consumers would be free to act as they intend to. In practice, constraints such as social influence, environmental situation, or unconscious habits would limit the freedom to act. The theory of planned behavior (TPB) attempts to overcome these limitations.

Expanding on the TRA theoretical model, Ajzen [4] added behavior control as a conceptual element to the model in order to overcome the limitations of behavior act. The Theory of Planed Behavior (TPB) defines Perceived Behavioral Control (PBC) as one's perception of the difficulty of performing a behavior. Further, the individual influencers of behavioral intention are theorized to exert an influence on each other. In addition to its impact on behavioral

Volume XI, No. 1, 2010 intentions, PBC is also thought to exert a separate influence on adoption behavior itself.

The Technology Acceptance Model (TAM) focuses on the issue of information systems adoption. TAM maintains that perceived usefulness and perceived ease of use both influence the adoption behavior of individual decision makers. Perceived Ease of Use additionally influences Perceived Usefulness. There are three approaches to extending the TAM; 1) introducing factors from related models, 2) introducing additional or alternative belief factors, and 3) examining antecedents and moderators of perceived usefulness and perceived ease of use [5]. TRA and TAM both have strong behavioral elements and assume that individuals will be free to act without limitation what they intend to perform. In practice, it is hard to implement.

Venkatesh, Morris, Davis, and Davis [6] incorporates TRA, TPB, TAM and other adoption behavior models into a proposed unified model that examines both perceptions and demographic elements. The Unified Theory of Acceptance and Use of Technology (UTATUT) model describes the intention to adopt a technology or behavioral intention as the result of four influences; performance expectancy, effort expectancy, social influence, and facilitating conditions. Each of these direct influences is impacted by a mixture of demographic factors (i.e., age and gender), experience, and the voluntariness of using the technology in question.

\section{Diffusion of Innovation (DOI)}

The Diffusion of Innovation (DOI) model, developed by Rogers [7], examines the issue of adoption in terms of the group perceptions of specific innovations and general adoption behaviors. The adoption behavior of individuals was classified into five archetypal forms with members of that behavioral grouping exhibiting general adoption behaviors across innovations entering their environment.

1. Innovators - venturesome, educated, multiple information sources

2. Early adopters - social leaders, popular, educated

3. Early majority - deliberate, many informal social contacts

4. Late majority - skeptical, traditional, lower socio-economic status

5. Laggards - Neighbors and friends are main info sources, fear of debt

Rogers DOI model characterizes the general acceptance of an innovation as a progressive process

Issues in Information Systems 
modeled as an S-curve. Individuals from various archetypal groups adopt innovations in their environment based on their own behavioral preferences and perceptions of the technology in terms of:

- Relative advantage - the degree to which the innovation is perceived as superior to the one it replaces

- Compatibility - the degree to which the innovation is perceived to show consistency with the existing values, past experiences, etc

- Trialability - the degree to which the innovation is perceived to be open for trials on a limited basis

- Observability - the degree to which the results of the innovation are perceived to be observable by the others

- Complexity - the difficulty, or degree to which the innovation is perceived to be understood and used

As a given innovation is perceived to have greater levels of relative advantage, trialability, observabiltiy, and compatibility, adoption increases. Complexity is seen as a negative influence in this model.

\section{RESEARCH MODEL AND HYPOTHESES}

The main purpose of the current research is to investigate the factors influencing usage (adoption and continued use) of $3 \mathrm{G}$ mobile phones and the degree to which specific factors account for individual acceptance or continuance behavior. It reviews the acceptance theories and the $3 \mathrm{G}$ technology background, develops process models of the usage of $3 \mathrm{G}$ mobile phones, including related factors during each step of adoption or continued use of $3 \mathrm{G}$ mobile phones. Variables in the models are divided into 3 stages as shown in Figures 1 and 2, and we will also evaluate and test the relationships to make sure the later prediction will be practical.

Stage1: Usefulness,

Enjoyment, Technicality, Fee. The first two factors are positive to the Perceived Value while the others are negative.

Stage 2: Perceived Value, Social Influence, and (Habit).

Stage 3: Adoption Intention (AI) or Continued Use (CU)
Figure 1. Process of $3 G$ Mobile Phone Adoption Intention

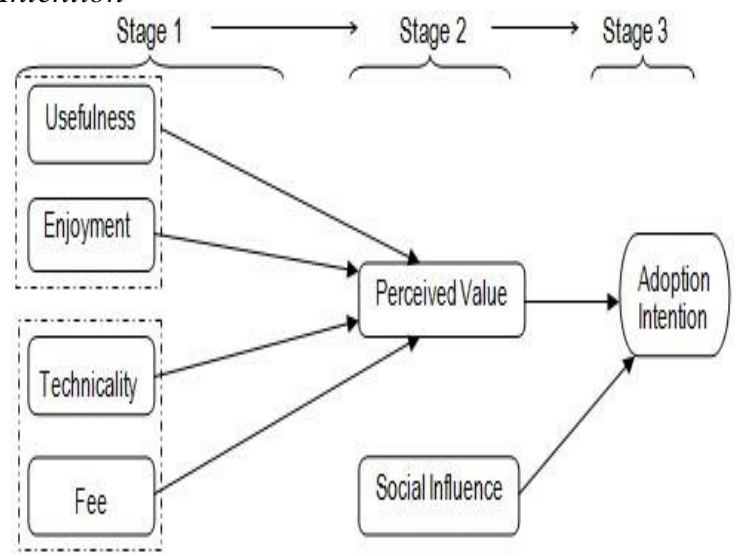

Figure 2. Process of 3G Mobile Phone Continued Use

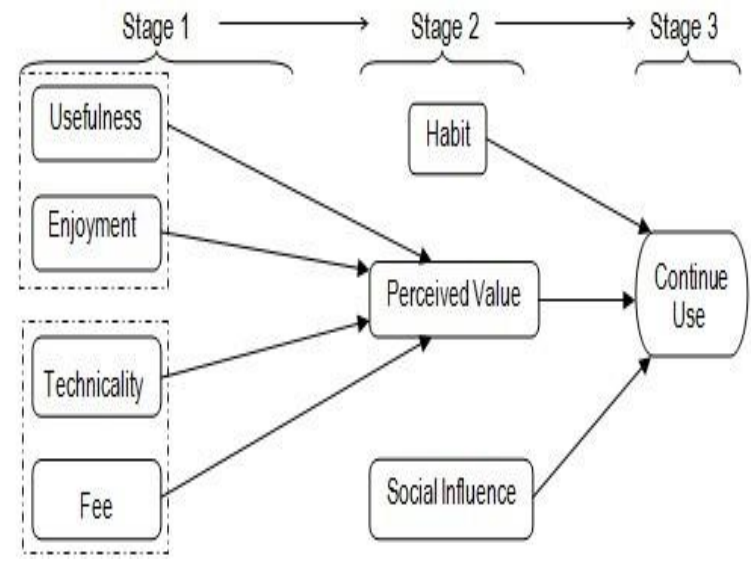

\section{Variables on Stage 1}

Usefulness (US), first proposed in TAM by Davis [8] and is defined as the total value a user perceives from using a new technology. Individuals base their behavior through perceived usefulness, which reflects the desire of individuals to put their perceived usefulness into practice and obtain the reward. The usefulness that stands for product quality will meet customer needs, driving a positive impact on Perceived Value.

Similarly, Usefulness in our model represents practical benefits or relative advantages for an individual. For example, an individual may improve personal activities by using $3 \mathrm{G}$ mobile phone to transfer files, check emails, or locate position. We assume that whether for an adoption or a continued use, Usefulness could always be significant and positive for Perceived Value. 
H11a: For potential adopters of $3 \mathrm{G}$ mobile phones, Usefulness has a positive influence on Perceived Value.

H11b: For current users of $3 \mathrm{G}$ mobile phones, Usefulness has a positive influence on Perceived Value.

Enjoyment (EN) represents the pleasure and joy that individuals get from the experience of using it, and is regarded to be an intrinsic motivation for individuals to adopt a new technology [9]. It stands for personal feelings about entertainment instead of the efficiency that belongs to Usefulness. People who enjoy the emotional value will raise their perceived value [10].

The enjoyment $3 \mathrm{G}$ mobile phones bring could be personal preference and applications of advanced games. Hence, the assumption is that Enjoyment is positive for both adoption and continued use.

H12a: For potential adopters of $3 \mathrm{G}$ mobile phones, Enjoyment has a positive influence on Perceived Value.

H12b: For current users of $3 \mathrm{G}$ mobile phones, Enjoyment has a positive influence on Perceived Value.

Technicality (TE) refers to the degree of difficulty that an individual percieves when attempting a new technology [11]. People have to give up their familiarity with the old technology and put efforts into new adoption. The ease of use is defined to be a sacrifice of adoption intention.

For 3G mobile phone, people may think it is too complicated to use with various applications. Therefore, we assume that technicality is negative for both adoption and continued use of 3G mobile phones.

H13a: For potential adopters of $3 \mathrm{G}$ mobile phones, Technicality has a negative influence on Perceived Value.

H13b: For current users of $3 \mathrm{G}$ mobile phones, Technicality has a negative influence on Perceived Value.

Fee (FE), usually called Price, could possibly be a critical factor that influences purchasing behavior [12]. In proposed model, FE includes the price of the $3 \mathrm{G}$ mobile phone and the additional fees associated with $3 \mathrm{G}$ services. $3 \mathrm{G}$ mobile handsets tend to be more expensive and generally require an additional charge for data transfer in addition to the cost of the cellular phone services. Because a 3G mobile phone is more advanced; it has a higher cost of ownership.

Volume XI, No. 1, 2010
Compared to the benefits that $3 \mathrm{G}$ mobile phones provide, the fee that needs to be paid to own a $3 \mathrm{G}$ mobile phone and $3 \mathrm{G}$ services will restrict the adoption behavior. FE is assumed to exert a negative influence on both initial adoption and continued use of $3 \mathrm{G}$ mobile phones.

H14a: For potential adopters of $3 \mathrm{G}$ mobile phones, Fee has a negative influence on Perceived Value.

H14b: For current users of 3G mobile phones, Fee has a negative influence on Perceived Value.

\section{Variables on Stage 2}

Perceived Value (PV) represents the overall impression of a new product after considering the benefits and sacrifices associated with adoption [13]. There is evidence from the current literature to support the assertion that Perceived Value has positive influence on Adoption Intention and Continued Use. Recent research by Malhotra and Malhotra [14] focuses on perceived usefulness and ease of use as primary drivers of Perceived Value. In the current study, Perceived Value is assumed to relate strongly to Adoption Intention and Continued Use.

H21a: For potential adopters of $3 \mathrm{G}$ mobile phones, Perceived Value has a Positive influence on Adoption Intention.

H21b: For current users of 3G mobile phones, Perceived Value has a Positive influence on Continued Use.

Social Influence (SN) refers to the degree of importance an individual places on using a $3 \mathrm{G}$ mobile phone based on suggestion by people that are important to them. Lewis [15] provides practical evidence that social influence does not have a significant effect on Perceived Value. In the current study, Social Influence is assumed to relate to Adoption Intention rather than Perceived Value.

H22a: For potential adopters of $3 \mathrm{G}$ mobile phones, Social Influence has a Positive influence on Adoption Intention.

H22b: For current users of $3 \mathrm{G}$ mobile phones, Social Influence has a Positive influence on Continued Use.

Habit $(\boldsymbol{H A})$ has recently driven some attention in the system of technology acceptance [16]. Kim, Park, and Morrison [17] proposed technology experience and trip experience as influences on adoption, and

\section{Issues in Information Systems}


that these two factors are equivalent to individual's habit. HA can be regarded as Path-dependence, which means people would prefer repeated behavior that they have been familiar with. In the continued use model (Figure 2), the habit of previously using a $3 \mathrm{G}$ mobile phone, to some extent, would lead to continued use regardless the perceived value.

H23b: For current users of $3 \mathrm{G}$ mobile phones, Habit has a Positive influence on Continued Use.

\section{METHODOLOGY}

Considering the topic of the paper, which is customer-based analysis of $3 \mathrm{G}$ mobile phone adoptions, data collection should necessarily focus on the viewpoints of individual adopters. A sample survey approach was deemed most appropriate for the current study based on the desire to emphasize specific behaviors independent of other environmental variables [18].

\section{Questionnaire Design}

The survey instrument (questionnaire) was developed using questions from previous studies relating to the adoption and continued use of technology. The questions were adapted to apply to $3 \mathrm{G}$ enabled cellular telephones. The term "3G enabled" cellular telephones were used because everyone with a $3 \mathrm{G}$ enabled telephone may not have $3 \mathrm{G}$ service. This is especially true in the United States where providers of this service are limited and coverage areas are still growing. Individuals that don't have $3 \mathrm{G}$ service were included because they still purchased the telephone. Ten students in a MBA level Management Information Systems (MIS) class reviewed the instrument for ambiguity and ease of use. Several changes were made as a result of their feedback (see Appendix 1).

The questionnaire began with an explanation of who was conducting the survey, the focus of the survey and confidentiality. The responses placed respondents into one of 3 groups: Group 1; those that currently own a $3 \mathrm{G}$ enabled cellular telephone, Group 2 ; those that intend to own a $3 \mathrm{G}$ enabled cellular telephone, and Group 3; those that do not intend to own a $3 \mathrm{G}$ enabled cellular telephone. The first question asked whether respondents owned a $3 \mathrm{G}$ enabled cellular telephone and determined whether respondents would complete side 1 or side 2 of the survey. Side 1 was for Group 1. Follow up questions related to the telephone brand and service provider were also asked. The first question on side 2 placed individuals that did not have a $3 \mathrm{G}$ enabled

Volume XI, No. 1, 2010 telephone into groups 2 and 3. A follow up open ended question asked group 2 respondents what brand they intend to own. There were 22 study variables on side 1 , and 14 on side 2; each utilized a 5 point Likert scale. Choices were: Strongly Agree, Agree, Undecided, Disagree, and Strongly Disagree. In addition there were 7 demographic questions at the end of the questionnaire that all respondents answered. They related to gender, country of origin, age, education level, education major, occupation, and income. The questions related to country, education major and occupation were open ended; the others were multiple choice. One demographic question (occupation) was eliminated after surveys were collected because it was inapplicable to the overwhelming number of respondents in the target sample.

\section{Sampling}

The field study was conducted using a convenience sample to test the model. The primary target group was university students in the United States and China. When possible, questionnaires were completed in person as a means of improving the study's response rate [19]. Chinese respondents provided a pool of respondents in a $3 \mathrm{G}$ market with a high degree of flexibility. In the Chinese $3 \mathrm{G}$ phone market, any handset may be used on the two national service providers. This is in contrast to the US market, where service providers tightly control which telephone handsets work on their network.

\section{Sample Surveys}

Responses from the questionnaire were entered into an Excel spreadsheet as they were collected. Open ended responses for telephone brand, and network provider were coded to include individual codes for all responses received. Countries were grouped as US, China, and the 7 continents excluding the US and China. Educational majors were placed in categories: Computer Information Systems (CIS), business majors excluding CIS, MBA, and non business majors. The responses were sorted to list the incomplete questionnaires at the bottom of the list. Analysis will include elements from Excel, SPSS and PLS.

\section{DATA ANALYSIS AND RESULTS}

A total of 165 questionnaires were collected; 35 were discarded because they were incomplete. Incomplete surveys were defined as lacking an answer to any study variable, or demographic question, or having more than one answer to any study variable. The remaining 130 usable surveys, split evenly into two 
groups; 1) Those that own $3 \mathrm{G}$ phones, and 2) Those that Do Not. Of the group that did not already own $3 \mathrm{G}$ phones, 28 expressed an intention to own one, and 37 indicated that they did not intend to own one (see Table 1).

Table 1. Descriptive statistics of the sample (130)

\begin{tabular}{|c|c|c|c|}
\hline \multirow{2}{*}{ Gender } & \multirow[b]{2}{*}{ Male } & Haven't $(\mathrm{N} 1=65)$ & \multirow{2}{*}{$\begin{array}{l}\text { Have } \\
(\mathrm{N} 2=65) \\
40\end{array}$} \\
\hline & & 26 & \\
\hline & Female & 39 & 25 \\
\hline \multirow[t]{3}{*}{ Age } & $<22$ & 37 & 31 \\
\hline & $22-26$ & 20 & 22 \\
\hline & $>27$ & 8 & 12 \\
\hline \multicolumn{2}{|c|}{ 3G MobileHave } & 0 & 65 \\
\hline \multirow[t]{2}{*}{ Phone } & Haven’t & $\begin{array}{l}\text { Intend to } 28 \\
\text { have }\end{array}$ & 0 \\
\hline & & $\begin{array}{l}\text { Not intend } 37 \\
\text { to have }\end{array}$ & \\
\hline
\end{tabular}

Analysis of Reliability and Independence of Independent Variables

Reliability coefficients were computed for each variable used in both the Adoption Intention and Continued Use models using SPSS. For variables used in the Adoption Intention Model (see Table 2), all items except for Fee (FE) were found to have acceptable (greater than 0.7 ) coefficients of reliability [20]. In the Continued Use Model (see Table 2), Social Influence (SN) and Enjoyment (EN) had reliability coefficients below the .7 threshold (.6097 and .6921 respectively). Reliability scores for FE in the Continued Use Model were within the acceptable range of values with a coefficient of .7981 .

The data collected was also examined to ensure that each of the independent variables were not highly correlated with each other $\left(\mathrm{R}^{2}>.7\right.$ or $\left.\mathrm{R}^{2}<-.7\right)$ [20]. Correlations between independent variables in both models show that none of the measures violate the criteria for independence.

Table2.. Reliability Analysis

\begin{tabular}{|c|c|c|}
\hline \multicolumn{3}{|c|}{ Variable Adoption Attention Continue Use } \\
\hline & Model & Model \\
\hline AI & $0.9752 \quad A I 1-A I 5$ & \\
\hline $\boldsymbol{C U}$ & & $0.7051 \mathrm{CU} 1 / \mathrm{CU} 2$ \\
\hline$P V$ & $1.0000 \quad P V 3$ & 0.7749 PV1-PV3 \\
\hline & & 0.6915 PV1/PV2 \\
\hline
\end{tabular}

Volume XI, No. 1, 2010 252

\begin{tabular}{|c|c|c|c|c|}
\hline & & & 0.6082 & PV1/PV3 \\
\hline & & & 0.8047 & $P V 2 / P V 3$ \\
\hline \multirow[t]{4}{*}{$S N$} & 0.7875 & SN1/SN2 & 0.4480 & SN1-SN3 \\
\hline & & & 0.2000 & SN1/SN2 \\
\hline & & & 0.6097 & SN1/SN3 \\
\hline & & & 0.1735 & SN2/SN3 \\
\hline $\boldsymbol{H A}$ & & & 0.8761 & $H B 1 / H B 2$ \\
\hline \multirow[t]{4}{*}{$U S$} & 0.6734 & US1-US3 & 0.0782 & US1-US4 \\
\hline & 0.7188 & US1/US2 & -0.6459 & US1/US2/US3 \\
\hline & 0.5409 & US1/US3 & 0.8176 & US1/US2/US4 \\
\hline & 0.3335 & US2/US3 & -0.3888 & US2/US3/US4 \\
\hline$E N$ & & & 0.6921 & EN1/EN2 \\
\hline \multirow[t]{4}{*}{$T E$} & & & 0.7015 & TE1-TE3 \\
\hline & & & 0.7127 & $T E 1 / T E 2$ \\
\hline & & & 0.5476 & TE1/TE3 \\
\hline & & & 0.5360 & TE2/TE3 \\
\hline \multirow[t]{4}{*}{$F E$} & 0.5947 & $F E 1-F E 3$ & 0.7819 & FE1-FE3 \\
\hline & 0.5500 & FE1/FE2 & 0.5947 & FE1/FE2 \\
\hline & 0.5439 & FE1/FE3 & 0.7224 & FE1/FE3 \\
\hline & 0.3829 & FE2/FE3 & 0.7981 & $F E 2 / F E 3$ \\
\hline
\end{tabular}

\section{Structural Evaluation}

An evaluation of the explanatory power of the independent variables on the dependent variables was performed. Correlation coefficients were computed between variables in State 1 and Stage 2, and between variables in Stage 2 and dependent variables (Stage 3) for both models. The US and EN constructs in these models would logically be expected to exert a positive influence on Perceived Value (PV), while TE and FE would be expected to exert a negative influence. All of the Stage 2 variables are hypothesized to increase (indicated by a positive R2 value) levels of the dependent variables Adoption Intention and Continued Use. The results obtained support the direction of all hypotheses (see Figure 3 and 4).

Figure 3. Structural relationship of Adoption Intention Model

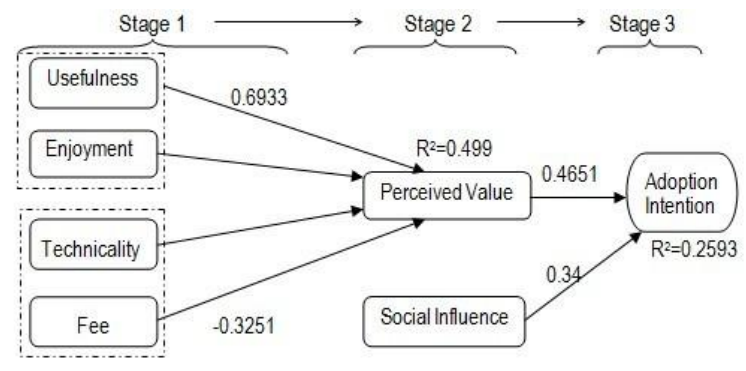

Issues in Information Systems 
Figure 4. Structural relationship of Continue Use Model

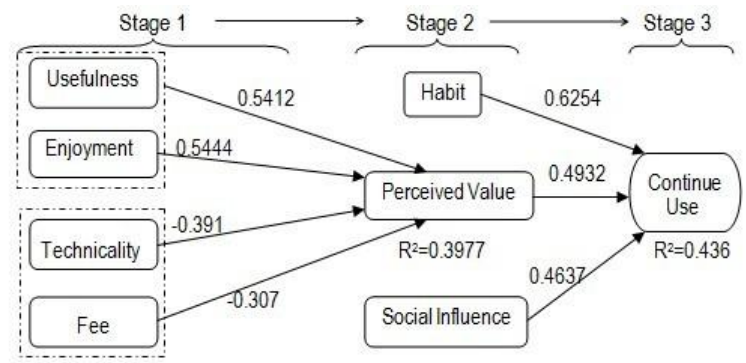

\section{CONCLUSION AND FUTURE DIRECTION}

The current pilot study has examined the applicability of conceptual models of technology adoption to the 3G mobile phone markets. Research models based on conceptual models of technology and innovation adoption from the information systems literature were developed. The first model is oriented towards the decision to initially adopt a technology. The second model, Continued Use, focuses on retention of a previously adopted technology. A survey instrument was developed and data was collected from culturally diverse sample population, which included respondents in the United States and China. This data was used to evaluate the reliability and validity of constructs in both proposed models.

Analysis of the correlation coefficients between independent variables indicates that measures are relatively independent of each other. Examinations of the structural coefficients within both of the proposed models provide support for the hypothesized direction of influence for each construct.

The adoption Intention is contengient on percieved value. The increased usefullness and lower fees will have the greatest impact on the percieved value, and if these are percieved as practical it will lead people to adopt the 3G telephone technology. Not examined in this study is the percieved value in relation to $2 \mathrm{G}$ and $2.5 \mathrm{G}$. If the precieved value is greater for $3 \mathrm{G}$ the the older above mentioned, G3 will me adopted. As predicited you will be more likely to adopt $3 \mathrm{G}$ if your peers are as well. Continued use will mainly come from percieved value which is influrnced by increased usefullness and enjoyability, lower fees and technicality, which will be enhanced for the consumer who has already apoted $3 \mathrm{G}$ based on their habbits. The use will continue until the next generation offers greater percieved value we have mentioned for $3 \mathrm{G}$. This last assumption and the comparison between $2 \mathrm{G}$ and $2.5 \mathrm{G}$ will need to be examed in future studies.

Volume XI, No. 1, 2010
Evaluation of reliability coefficients indicate that several constructs as measured were not sufficiently robust enough, indicating that additional testing of the survey measures is required. Although the respondents were relatively homogeneous in terms of age, differences based on gender and nationality (American versus Chinese) was not examined. Additional analysis that includes groupings based on culture and market organization will be required to eliminate these issues as potential causes of low reliability coefficients for several constructs.

\section{REFERENCES}

1. Tang, L., Key success factors in $3 G$ services adoption: A consumer perspective. 2008, E.S. C. Rennes School of Business. p. 1-7.

2. Agarwal, R. and J. Prasad, The role of innovation characteristics and perceived voluntariness in the acceptance of Information Technologies. Decision Sciences, 1997. 28(3): p. 557-582.

3. Ajzen, I. and M. Fishbein, The influence of attitudes on behavior, in The Handbook of attitudes, B.T.J. D. Albarracin, \& M.P. Zanna, Editor. 2005, Lawrence Erlbaum: Mahwah, NJ. p. 173-222.

4. Ajzen, I., The theory of planned behavior. Organizational Behavior and Human Decision Processes 1991. 50(2): p. 179-211.

5. Wixom, B.H. and P.A. Todd, A theoretical integration ofuser satisfaction and technology acceptance. Information Systems Research, 2005. 16(1): p. 85-102.

6. Venkatesh, V., et al., User acceptance of information technology: Toward a unified view. MIS Quarterly, 2003. 27(3): p. 425478.

7. Rogers, E., Diffusion of Innovations. 1995, New York, NY: Free Press.

8. Davis, F.D., Perceived usefulness, perceived ease of use, and user acceptance of Information Technology. MIS Quarterly, 1989. 13(3): p. 319-339.

9. Agarwal, R. and E. Karahanna, Time flies when you're having fun: cognitive absorption and beliefs about Information Technology. MIS Quarterly, 2000. 24(4).

10. Venkatesh, V., Creation of favorable user perceptions: Exploring the role of intrinsic motivation. MIS Quarterly, 1999. 23(2): p. 239.

11. Kim, H., C. Hock, and S. Gupta, Valuebased adoption of mobile internet: an

Issues in Information Systems 
empirical investigation. Decision Support Systems, 2007. 43: p. 111-126.

12. Voss, G.B., A. Parasuraman, and D. Grewal, The roles of price, performance, and expectations in determining satisfaction in service exchanges. Journal of Marketing, 1998. 62(4): p. 46-61.

13. Sirdeshmukh, D., J. Singh, and B. Sabol, Consumer trust, value, and loyalty in relational exchanges. Journal of Marketing, 2002. 66(1)

14. Malhotra, A. and C.M. Malhotra, A relevancy-based services view for driving adoption of wireless web services in the U.S. . Communications of the ACM, 2009. 52(7): p. $130-134$.

15. Lewis, W., R. Agarwal, and V. Sumbamurthy, Sources of influence on beliefs about information technology use: An empirical study of knowledge workers. MIS Quarterly, 2003. 27(4): p. 657-678.

16. Limayem, M., S.G. Hirt, and C.M. Cheung, How habit limits the predictive power of intention. MIS Quarterly, 2007. 31(4): p. 705-737.

17. Kim, D., J. Parks, and A.M. Morrison, $A$ model of traveler acceptance of mobile technology, in INTERNATIONAL JOURNAL OF TOURISM RESEARCH. 2008, Wiley InterScience

18. Creswell, J.W., Research Design. 1994, Thousand Oaks, CA: Sage.

19. Shao, A.T. and K.Z. Zhou, Marketing Research. 3rd ed. 2007, Mason, OH: Thompson.

20. Barcley, D., R. Thompson, and C. Higgins, The Partial Least Squares (PLS) approach to causal modeling: personal computer adoption and use. Technology Studies, 1995. 2(2): p. 285-309.

APPENDIX 1: Operationalization of the model variables a. Model of Adoption Intention

\begin{tabular}{lll}
\hline variable & item & Description. \\
\hline $\begin{array}{l}\text { Adoption } \\
\text { intention }\end{array}$ & AI1 & $\begin{array}{l}\text { Plan to use a 3G cell phone } \\
\text { within 6 months. } \\
\text { AI2 }\end{array}$ \\
Plan to use a 3G cell phone \\
within 12 months. \\
AI4 & $\begin{array}{l}\text { Intend to use a 3G cell phone } \\
\text { in the future. } \\
\text { Predict to use a 3G cell phone } \\
\text { in 6 months. } \\
\text { Predict to use a 3G cell phone }\end{array}$
\end{tabular}

Volume XI, No. 1, 2010

254 in 12 months.

Perceived PV1 Overall, the use of a $3 \mathrm{G}$ cell value phone would deliver good value to me.

Social influence

SN1 People who influence my behavior think that I should use a $3 \mathrm{G}$ cell phone.

SN2 People who are important to me do not think that I should use a $3 \mathrm{G}$ cell phone(reversed).

Usefulness US1 A 3G cell phone would provide many benefits to me.

US2 Using a 3G cell phone would enhances my performance at school/work.

US3 I would not find a 3G cell phone useful in my daily life(reversed).

Perceived FE1 The fee I would have to pay fee for a $3 \mathrm{G}$ cell phone is too high.

FE2 Web-enabled cell phones offer poor value for the money.

FE3 At its current price, access to the WWW through a $3 \mathrm{G}$ cell phone is a good value (reversed).

b. Model of Continue Use

\begin{tabular}{|c|c|c|}
\hline Variable & Item & Description \\
\hline \multirow[t]{2}{*}{ Continue use } & CU1 & $\begin{array}{l}\text { If I could, I would like to } \\
\text { continue my use of a } 3 \mathrm{G} \text { cell } \\
\text { phone. }\end{array}$ \\
\hline & CU2 & $\begin{array}{l}\text { I predict I will not keep using } \\
\text { a } 3 G \text { cell phone(reversed). }\end{array}$ \\
\hline \multirow[t]{2}{*}{ Habit } & HA1 & $\begin{array}{l}\text { Using a } 3 \mathrm{G} \text { cell phone has } \\
\text { become automatic to me. }\end{array}$ \\
\hline & HA2 & $\begin{array}{l}\text { When faced with a particular } \\
\text { task, using a } 3 \mathrm{G} \text { cell phone is } \\
\text { an obvious choice to me. }\end{array}$ \\
\hline \multirow[t]{3}{*}{$\begin{array}{l}\text { Perceived } \\
\text { value }\end{array}$} & PV1 & $\begin{array}{l}\text { Compared to the fee I need to } \\
\text { pay, the use of a } 3 \mathrm{G} \text { cell } \\
\text { phone offers value for the } \\
\text { money. }\end{array}$ \\
\hline & PV2 & $\begin{array}{l}\text { Compared to the effort I put } \\
\text { in, the use of } 3 \text { Gcellphone is } \\
\text { beneficial to me. }\end{array}$ \\
\hline & PV3 & $\begin{array}{l}\text { Overall, the use of a } 3 \mathrm{G} \text { cell } \\
\text { phone has become automatic } \\
\text { to me. }\end{array}$ \\
\hline \multirow[t]{2}{*}{$\begin{array}{l}\text { Social } \\
\text { influence }\end{array}$} & SN1 & $\begin{array}{l}\text { People who influence my } \\
\text { behavior think that I should } \\
\text { use a } 3 \mathrm{G} \text { cell phone. }\end{array}$ \\
\hline & $\mathrm{SN} 2$ & $\begin{array}{l}\text { People who are important to } \\
\text { me do not think that I should }\end{array}$ \\
\hline
\end{tabular}

Issues in Information Systems 


\begin{tabular}{|c|c|c|}
\hline & & \\
\hline & SN3 & $\begin{array}{l}\text { In general, my job/school has } \\
\text { supported my use of } 3 \mathrm{G} \text { cell } \\
\text { phone. }\end{array}$ \\
\hline Usefulness & US1 & $\begin{array}{l}\text { A } 3 G \text { cell phone provides } \\
\text { many benefits to me. }\end{array}$ \\
\hline & US2 & $\begin{array}{l}\text { Using a 3G cell phone } \\
\text { enhances my performances at } \\
\text { school/work. }\end{array}$ \\
\hline & US3 & $\begin{array}{l}\text { I do not find a } 3 \text { Gcellphone } \\
\text { useful in my daily life } \\
\text { (reversed). }\end{array}$ \\
\hline & US4 & $\begin{array}{l}\text { Using a } 3 G \text { cell phone } \\
\text { improves my chances of } \\
\text { achieving things I find } \\
\text { important. }\end{array}$ \\
\hline Enjoyment & EN1 & $\begin{array}{l}\text { I have fun using a } 3 \mathrm{G} \text { cell } \\
\text { phone. }\end{array}$ \\
\hline & EN2 & $\begin{array}{l}\text { I do not enjoy using a } 3 \mathrm{G} \\
\text { cell phone(reversed). }\end{array}$ \\
\hline Technicality & TE1 & $\begin{array}{l}\text { I can connect quickly to the } \\
\text { WWW through a } 3 G \text { cell } \\
\text { phone(reversed). }\end{array}$ \\
\hline & TE2 & $\begin{array}{l}\text { A } 3 \mathrm{G} \text { cell phone has a slow } \\
\text { response time for the online } \\
\text { activities. }\end{array}$ \\
\hline & TE3 & $\begin{array}{l}\text { I find a } 3 \mathrm{G} \text { cell phone hard to } \\
\text { use. }\end{array}$ \\
\hline Perceived fee & FE1 & $\begin{array}{l}\text { The fee I have to pay for a } \\
3 \mathrm{G} \text { cell phone is too high. }\end{array}$ \\
\hline & FE2 & $\begin{array}{l}\text { Web-enabled cell phones } \\
\text { offer poor value for the } \\
\text { money. }\end{array}$ \\
\hline & FE3 & $\begin{array}{l}\text { At its current price, access to } \\
\text { the WWW through a } 3 \mathrm{G} \text { cell } \\
\text { phone is a good value } \\
\text { (reversed). }\end{array}$ \\
\hline
\end{tabular}

